\title{
I nclusão social pelo trabalho decente: oportunidades, obstáculos, políticas públicas
}

I GNACY SACHS

\section{Para quando a "fábrica de empregos"?}

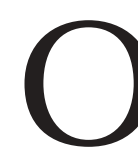

BRASIL ENTROU no século XXI com um aparelho industrial moderno e diversificado e um setor de agronegócios que Ihe confere a liderança mundial em vários setores ${ }^{1}$. No entanto, a sua estrutura ocupacional reflete 0 atraso social do país. Segundo a PN AD de 2002, os empregados sem carteira assinada constituíam $24,2 \%$ da PEA e os empregados por conta própria $22,3 \% 4,2 \%$ das pessoas ocupadas trabal havam unicamente para o próprio consumo, e 11,7\%não tinham rendimento monetário algum. $27,1 \%$ dos trabalhadores tinham rendimentos inferiores ou iguais a um salário mínimo, 26,3\% de um a dois salários mínimos, $12,4 \%$ de dois a três salários mínimos, enquanto apenas $1,3 \%$ superava os vinte salários mínimos. A economia brasileira é constituída por uma quantidade de empresas modernas e eficientes, algumas de statusmundial, imerso num sem número de atividades de baixíssima produtividade. A riqueza está concentrada nela ao passo que uma parcela importante da população busca a sobrevivência na informalidade? .

Para acomodar os novos contingentes que entram na força de trabalho, de ordem de 1,5 milhão, e saldar a imensa dívida social acumulada sob a forma de desemprego e subemprego ${ }^{3}$ durante quarenta anos de crescimento econômico e de modernização rápidos porém social mente perversos, seguidos de mais de duas décadas quase perdidas, o Brasil precisa se transformar numa gigantesca fábrica de empregos. Para tanto, deverão ser gerados de dois a 2,5 milhões postos de trabalho, número este definido pela O IT como decente, ou seja, empregos e/ ou auto-empregos realizados em boas condições e convenientemente remunerados, fazendo com que a força de trabalho empregada cresça a um ritmo anual de pelo menos $2,5 \%$.

No entanto, como bem observou José Pastore, "o Brasil vive um tempo paradoxal: euforia no mercado financeiro e desespero no mercado do trabalho" 4 . O s resultados alcançados no primeiro ano do governo do Presidente Lula no que diz respeito à redução por dois terços da taxa de risco, revalorização dos papéis brasileiros, balança comercial altamente positiva, superávit fiscal superior a 5\% do PIB e valorização das bolsas, mereceram rasgados elogios por parte de 
altos funcionários do Banco M undial. D avid de Ferranti e Vinod Thomas, respectivamente vice-presidente do Banco $M$ undial para a América $L$ atina e diretor do escritório desta entidade no B rasil, chegaram a falar de um "consenso de Braślia" - novo modelo que viria a substituir o consenso de Washington, compatibilizando o desenvolvimento econômico com o progresso social. Para eles, 0 consenso de Brasília aponta para um novo paradigma de desenvolvimento, de maior interesse para o conjunto dos países do Sul ${ }^{5}$.

Assim, o choque de credibilidade junto à comunidade internacional de banqueiros foi coroado de sucesso, mas ao preço de um desempenho medíocre da economia real: no ano de 2003 a taxa de crescimento foi praticamente nula, 0 rendimento médio do trabalho caiu $12,9 \%$ nas zonas metropolitanas, pelo sexto ano seguido, e a taxa de desemprego só não aumentou porque foram criados numerosos subempregos sem rendimento monetário ou com rendimentos abaixo de um salário mínimo.

0 aumento do trabalho precário foi a principal característica do mercado em 2003. Entre dezembro de 2002 e dezembro de 2003, subiu em 812 mil o número de trabalhadores ocupados nas seis principais regiões metropolitanas. Em contrapartida, a quantidade de empregados com carteira de trabalho no setor privado encolheu em 907 mil, e enquanto cresceu em 446 mil o número de empregados sem carteira e em 334 mil o de trabal hadores por conta própria6.

U m estudo recente realizado pelo Instituto de Economia da U FRJ a pedido da Cepal e coordenado por D avid Kupfer, apresentou dados estarrecedores sobre a eliminação de empregos que se seguiu à abertura da economia brasileira em 1990. A modernização tecnológica do país fechou 8,98 milhões de postos de trabalho no setor agropecuário, 3,63 milhões na indústria manufatureira, 902 mil na administração pública e 757 mil na construção civil. A produtividade do trabalho na agropecuária cresceu, de 1990 a 2001, em média, 5,12\%ao ano, e na indústria, 2,52\% Por sua vez, as importações provocaram a redução de 1,54 miIhão de postos de trabalho.

Ao todo, perderam-se assim, em onze anos, 12,3 milhões de empregos. Ao mesmo tempo, criaram-se na economia doméstica 11,96 milhões de empregos e nas exportações 3,58 milhões, com um saldo global positivo, onze anos, de 3,24 milhões. Este último número deve ser comparado com a entrada anual de 1,5 a 1,8 milhão de pessoas novas no mercado de trabalho. 0 s anos 2002 e 2003, para os quais os dados não estão ainda disponíveis, conheceram um desempenho similar. 0 crescimento pífio da economia não compensa os efeitos da modernização tecnológica?.

Esses números merecem alguns reparos. A perda de empregos industriais é, em parte, compensada pela criação de ocupações no setor de serviços, para o qual as indústrias terciarizaram atividades de limpeza, manutenção etc. A questão que se coloca é saber se a modernização poderia ter sido menos destruidora de empregos, caso fossem aplicadas políticas diferentes na agricultura, na indús- 
tria e no comércio exterior, já que, ao se ultrapassar certos limites, o que Schumpeter chamava de destruição criadora passa a ser destruição tout-court.

Q ualquer que seja a resposta dada a esta pergunta (pessoalmente penso que boa parte do estrago poderia ter sido evitada) comprende-se que, nestas condições, o presidente Lula e vários ministros tenham proclamado em vários pronunciamentos recentes a geração de empregos como a prioridade máxima para 0 ano 2004, reconhecendo ao mesmo tempo, com razão, que o crescimento, por si só, não bastava para assegurar uma trajetória da economia com uma intensidade de emprego satisfatória.

0 Brasil não está isolado frente a este desafio, bem ao contrário ${ }^{8}$. Praticamente o mundo inteiro está às voltas com a epidemia de cresci mento sem emprego (jobless growth), inclusive os Estados U nidos, onde a retomada recente não se acompanha de criação satisfatória de empregos.

O crescimento sem emprego resulta de uma combinação de vários fatores:

- introdução agressiva do progresso técnico poupador de trabalho nasindústrias;

- renúncia a uma política de salários altos (o fordismo) sacrificados no altar de uma busca desenfreada de lucros financeiros e a conseqüente redução do ritmo de crescimento da demanda efetiva, uma das causas principais do crescimento pífio;

- deslocamento das produções intensivas em mão-de-obra para plataformas de exportação situadas em países periféricos que se satisfazem com a competitividade espúria, lograda por meio de salários excessivamente baixos, longas jornadas de trabal ho e ausência de proteção social ${ }^{10}$.

H á quem acredite que a epidemia de crescimento sem emprego só pode ser combatida por taxas de crescimento econômico excessivamente elevadas ${ }^{11}$ que não são contabilizadas na conjuntura internacional atual. Elas teriam que ser de $5 \%$ ao ano ou mais, enquanto nada for feito para modificar a intensidade em empregos dos paradigmas atuais de crescimento. Em outras palavras, o desemprego, o subemprego e a exclusão social afiguram-se como um mal necessário a ser minorado por vigorosas políticas assistenciais.

$N$ este texto, adotaremos uma linha diferente. Continuamos a pensar que é necessário e possível desenhar estratégias de desenvolvimento que asseguram a todos a inclusão social pelo trabal ho decente ${ }^{12}$ atuando simultaneamente sobre as taxas de crescimento econômico e os coeficientes de elasticidade de emprego/ crescimento. Enquanto persistirem as grandes diferenças sociais e os níveis de exclusão que conhecemos hoje no Brasil, as políticas sociais compensatórias serão indispensáveis, além da urgência em promover o acesso universal aos serviços sociais de base - educação, saúde, saneamento, moradia. Porém, o emprego e 0 auto-emprego decentes constituem a melhor maneira de atender às necessidades sociais por duas razões: 
- a inserção no sistema produtivo oferece uma solução definitiva, enquanto as medidas assistenciais requerem financiamento público recorrente;

- em termospsicológicos, o exercício do direito ao trabal ho promove a autoestima, oferece oportunidades para a auto-realização e o avanço na escala social, ao contrário do desânimo e da falta de perspectivas vivenciados por assistidos crônicos.

Para avançar nessa direção, o Brasil deverá buscar uma solução ao seguinte dilema: "Sem emprego a equação brasileira não fecha. Sem crescimento acelerado e industrialização o Brasil não tem conserto" ${ }^{13}$.

$\mathrm{N}$ a realidade, o desenvolvimento é um processo com duas vertentes que devem ser compatibilizadas:

- em termos econômicos, trata-se de diversificar e complexificar as estruturas produtivas, logrando ao mesmo tempo incrementos significativos e contínuos da produtividade de trabalho, base do aumento do bem-estar;

- em termos sociais, deve-se, ao contrário, promover a homogeneização da so ciedade ${ }^{14}$, reduzindo as distâncias so ciais que separam as diferentes camadas da po pulação.

Infelizmente, o crescimento econômico promovido pelas forças do mercado traz, mesmo quando bem-sucedido em termos econômicos, resultados sociais opostos aos almejados: as diferenças sociais aumentam, a riqueza se concentra na mão de uma minoria ao mesmo tempo em que de uma parcela importante da população é marginalizada.

Q uando isto acontece, por maiores que sejam as taxas de crescimento do PIB e o progresso alcançado na modernização do aparelho produtivo, o país avança na direção de um "maldesenvolvimento", sobretudo quando se lança mão da inflação para eludir os conflitos distributivos. Como já dissemos, o Brasil passou por esta experiência nas décadas do "milagre", quais sejam de 1940-1980. o quarto de século de baixo crescimento que se seguiu acrescentou, a uma herança já complicada, o peso de uma dívida externa e interna de difícil administração.

Voltando ao nosso dilema, é normal que recursos financeiros vultosos sejam mobilizados para a indispensável expansão do núcleo modernizador da economia brasileira constituído por indústrias e agronegócios de alta tecnologia, amparados por uma infra-estrutura eficiente nos setores de energia e transporte, e capazes de expandir as exportações em condições de competitividade genuína, baseada em conhecimentos, tecnologias avançadas e aproveitamento das vantagens comparativas naturais.

Este processo deverá ainda respeitar os preceitos de sustentabilidade ambiental. D evemos nos esforçar por desenhar uma estratégia de desenvolvimento que seja ambientalmente sustentável, economicamente sustentada e socialmente includente ${ }^{15}$, vale dizer, capaz de caminhar na direção de pleno emprego e autoemprego decentes no sentido que a O IT dá a este adjetivo, ou seja, condições de trabalho e remuneração dignas. 
No entanto, o crescimento do núcleo modernizador vai gerar pouquíssimos empregos diretos, ou mesmo reduzir, como vimos, o seu número. D aí a importância de aproveitar da melhor maneira possível o multiplicador de empregos indiretos, tema que trataremos em detal he no decorrer deste texto, e que funciona em dois níveis:

- através de empregos criados a montante e a juzante das grandes indústrias, nas empresas fornecedoras de insumos e serviços, e nas que usam como insumos os produtos destas indústrias;

- através da demanda por bens e serviços, gerada pelo consumo dos trabaIhadores destas indústrias (aqui aparece o papel do fordismo);

M esmo assim, estaremos ainda longe da conta, no que diz respeito ao volume de empregos criados com relação à demanda representada pela entrada dos novos contingentes de força de trabalho, além dos milhões de desempregados e subempregados à espera de trabal ho decente. Por isso, deverão ser aproveitadas ao máximo todas as oportunidades de geração de empregos nos setores da economia nos quais o crescimento puxado pel o emprego ${ }^{16}$ é ainda possível, ou seja, nos quais existem margens de liberdade para escolher tecnologias intensivas em mãode-obra.

Acreditamos que, ao contrário de muitos países, o Brasil apresenta potencialidades excepcionais para avançar nesta direção.

0 fato de possuir uma fronteira agrícola ainda não explorada até o fim, junto com a maior biodiversidade do mundo e climas diversos e amenos favoráveis à produtividade primária ${ }^{17}$, permite pensar num novo ciclo de desenvolvimento rural. O s diferentes setores de produção de bens e serviços'não comerciávés (non tradables), portanto não sujeitos à competição internacional, poderão resultar na criação de numerosos empregos e auto-empregos, em particular na área de serviços. Paradoxalmente, a baixa produtividade do trabalho nas atividades informais abre oportunidades para um avanço rápido à condição de desenhar um conjunto de políticas públicas baseado no conceito de tratamento desigual dos desiguais (discriminação positiva em favor dos atores mais fracos), favorecendo as saídas da informalidade. Por fim, cabe mencionar o desafio de construir sinergias positivas entre as grandes empresas e os empreendimentos de pequeno porte.

A meta de transformar o Brasil numa fábrica de empregos afigura-se difícil, porém perfeitamente factível. No que segue, procuraremos justificar o nosso otimismo.

\section{C rescimento, produtividade e emprego}

A taxa de crescimento da economia $r$ é aproximadamente igual à taxa de crescimento da produtividade do trabalho $\mathrm{p}$ mais a taxa de crescimento do emprego e:

$$
r=p+e
$$


Podemos chamar de cresci mento extens ivo, aquele logrado unicamente através do aumento do emprego $(p=0)$ e de crescimento intensivo, aquele obtido através dos aumentos de produtividade $(e=0)$, sendo que ocorrem ainda casos onde $p$ é maior do que $r$ e o crescimento, por mais forte que seja, se traduz por reduções de emprego.

Para o planejador, o dilema consiste em encontrar um ponto de equilíbrio entre crescimento extensivo e intensivo. $\mathrm{N}$ a medida em que se considera como um imperativo social a absorção, no mínimo, de todo o contingente de jovens que ingressa na força de trabalho, e deve-se, garantir esse objetivo. Se a força do trabalho aumenta a $2 \%$ ao ano, e min. $=2$.

0 quadro seguinte permite de ler a taxa de crescimento do emprego e em função das diferentes combinações de $r$ e p:

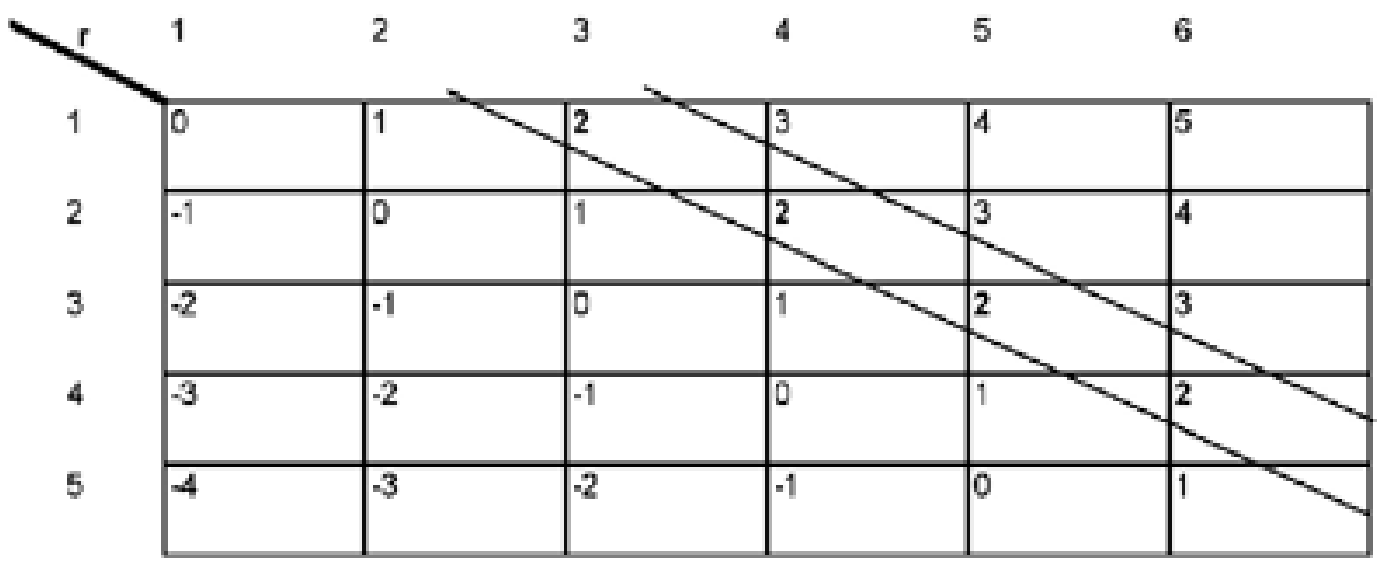

As boas soluções estão à direita da diagonal de e $=2$. É claro que sua efetivação sería mais fácil para valores altos de $r$. Infelizmente, como já dissemos, na atual conjuntura não se pode esperar que o Brasil logre o pleno emprego por meio de crescimento acelerado, pelo menos nos próximos anos. D aí a necessidade de desenhar políticas finas que permitam compensar o crescimento intensivo nas indústrias modernas que incorporam as tecnologias de ponta, por taxas maiores de crescimento dos setores da economia onde o crescimento extensivo ainda faz sentido.

Em outras palavras, trata-se de incentivar um mix apropriado de atividades, atuando em três níveis:

- reequilibrando os setores (mais serviços, e em particular mais serviços sociais, maior ênfase sobre a construção de moradias e obras públicas);

- privilegiando dentro dos setores produções naturalmente mais intensivas em mão-de-obra, na agricultura ${ }^{18}$, na indústria e no artesanato;

- incentivando em termos microeconômicos a escolha de tecnologias apropriadas, com especial destaque para o uso de tecnologias híbridas ${ }^{19}$.

Para aprofundar esta discussão, seria interessante poder contar com dados setoriais que relacionam a evolução de r, p e enos últimos dez anos, e cotejá-los 
com dados microeconômicos que ilustram a amplitude das funções de produção que a um dado momento coexistem em cada setor. A coexistência de assincronismos é uma característica de subdesenvolvimento. Por outro lado, a incorporação do progresso técnico nunca se faz de uma vez só ${ }^{20}$.

Acreditamos que um estudo deste tipo pode ser realizado a partir dos dados existentes no IBGE, I pea, BN D ES e Fiesp. Sem esperar por seus resultados, podemos adiantar o estudo do potencial da geração de empregos e de autoempregos decentes no Brasil, apontando para os setores que oferecem as maiores oportunidades.

\section{U m novo ciclo de desenvolvimento rural ${ }^{21}$}

Acreditamos que o maior potencial de empregos e de auto-empregos decentes esteja no mundo rural, em que pese a alta taxa de redução de postos de trabal ho observada atualmente no setor agropecuário. $\mathrm{N}$ ão acreditamos que 0 B rasil esteja fadado a repetir a experiência dos países hoje industrializados, que conseguiram reduzir a uma percentagem insignificante o emprego na agricultura e absorveram com sucesso o excedente de mão-de-obra rural nas cidades, principalmente nas indústrias. Esta transformação não seria, aliás, possível para os países euro peus sem a emigração massiva para as Américas e o papel desempenhado pelas colônias.

As condições, no entanto, mudaram. A desindustrialização em curso torna impossível a reprodução deste padrão, tanto mais que o Brasil já efetuou uma urbanização prematura e excessiva22. É um erro supor que os refugiados do campo que migram para as favelas e os bairros periféricos das cidades, se transformam automaticamente em citadinos. São candidatos à urbanização cuja efetivação dependerá da criação de empregos e al ojamentos decentes e de condições para o exercício da cidadania. $\mathrm{N}$ a visão otimista, as favelas funcionam como purgatórios. Tudo indica que o custo da urbanização dos que já foram arraigados do campo, será muito mais elevado do que seria a geração de empregos e de auto-empregos decentes e a promoção do progresso civilizatório no meio rural.

Segundo dados do Pronaf, a agricultura familiar é hoje responsável por $77 \%$ da ocupação no meio rural e responde por $37 \%$ da produção agrícola brasileira. Cerca de $84 \%$ dos cinco milhões de estabelecimentos agropecuários são de agricultores familiares. D e acordo com um estudo do I base, cada operação de financiamento do Pronaf (no ano 2003, 1,147 milhão de contratos num valor total de $R \$ 3,8$ bilhões) estaria garantindo a manutenção de três empregos e a geração de 0,58 ocupações ${ }^{23}$. A agricultura familiar tem, portanto, ainda, um longo futuro à frente, tanto mais que a sua modernização gradual afigura-se viável e que sem a sua consolidação dificilmente o Brasil poderá contar com um sistema eficiente de segurança alimentar. Parte do agronegócio, que tanta importância tem para o comércio exterior do Brasil, é constituida por agricultores familiares bem-sucedidos, por exemplo, no setor de aves ou de carne suína. N ão 
se deve considerar a produção mecanizada de grãos (soja) que cria um número diminuto de empregos diretos, como representativa do conjunto de agronegócios.

A reforma agrária bem conduzida, cobrando resultados produtivos dos seus beneficiários e incentivando a lógica empreendedora dos assentados ${ }^{24}$, com destaque para to das as formas de empreendedorismo coletivo - cooperativas de produção, venda, poupança e crédito, outras formas de associativismo - pode ampliar o setor da agricultura familiar viável gerando empregos e auto-empregos a um custo inferior a qualquer alternativa urbana.

$\mathrm{N}$ ão esqueçamos que a racionalidade da economia familiar é diferente da economia de empresa, e que os membros da família não imputam ao seu tempo de trabalho um salário como se estivessem empregados como assalariados. Daí resulta a resiliência dos agricultores familiares submetidos à concorrência dos produtores modernos ${ }^{25}$.

Para todos os efeitos, podemos considerar a unidade familiar como possuidora de uma reserva potencial de tempo de trabal ho a ser aproveitada como uma verdadeira reserva de desenvolvimento. Por isso, longe de serem meramente políticas sociais, a reforma agrária e as medidas de apoio à agricultura familiar afiguram-se como alavancas importantes da estratégia de desenvolvimento ${ }^{26}$. 0 que importa é criar condições para que esta reserva de tempo de trabalho se transforme em trabalho efetivo mediante o aumento da escala das produções já existentes, acréscimo de novos módulos ao sistema familiar de produção agropecuária e investimentos não monetários no desmatamento, na criação de pastos, nas benfeitorias e na moradia ${ }^{27}$. Acreditamos que a complexificação de sistemas familiares de produção agropecuária e sua adequação aos diferentes ecossistemas constituem uma prioridade para as pesquisas da Embrapa. 0 progresso da agricultura brasileira requer soluções intensivas em conhecimentos e em trabalho, porém poupadoras do capital, da energia fóssil e de recursos naturais escassos (como a água no semi-árido). Esta equação difere da dos países industrializados, empenhados numa agricultura intensiva em capital e poupadora de mão-de-obra.

U m outro fator geralmente ausente nas políticas de apoio à agricultura familiar é a oferta de tecnologias apropriadas para a modernização das produções de subsistência, mediante aumento dos rendimentos e/ ou redução do tempo de trabalho que poderá ser aproveitado nas produções voltadas ao mercado ou nas atividades não econômicas.

A experiência de numerosos países em desenvolvimento mostra que o não aproveitamento desta reser va de desenvol vi mento constitui um grave erro de estratégia, já que o êxodo rural prematuro e excessivo gera problemas de difícil solução no meio urbano. Para todos os países que têm ainda uma fronteira rural a explorar, vale o conceito de industrialização sem descamponização(industrialisation sans dépaysannisation) proposto pelo economista egípcio I smaïl Sabri Abdallah. 
A observação sobre a necessidade de assegurar um futuro a longo prazo para a agricultura familiar vale para o conjunto dos países do Sul. Atualmente, cerca da metade da população mundial é constituída de agricultores familiares. O s mais atrasados do ponto de vista técnico têm uma produtividade de trabalho ínfima, que chega a ser mil vezes menor que a dos agricultores modernos altamente mecanizados ${ }^{28}$. Estes poderiam, em pouco tempo, varrer do mercado a massa dos agricultores familiares, com conseqüências sociais dramáticas na ausência de estratégias de desenvolvimento que protejam os agricultores familiares e, ao mesmo tempo, promovam a sua gradual modernização, reduzindo a disparidade hoje existente na produtividade do trabalho.

0 importante é raciocinar em termos de desenvolvimento rural e não meramente agrícola, promoven do a pluriatividade dos membros das famílias de agricultores e incentivando os empregos rurais não agrícolas os mais diversos: nas agroindústrias, no artesanato, nas pequenas indústrias decentralizadas, na prestação de serviços técnicos, de manutenção, sociais e pessoais, no transporte, na construção, no desenvolvimento de atividades turísticas, sem esquecer a administração pública. Entre 1985 e 2001, a China conseguiu criar 140 milhões de atividades não agrícolas nas zonas rurais. Elas ocupam atualmente 168 milhões de pessoas, a comparar com 28 milhões em $1978^{29}$. H oje, este potencial se esgotou, mas a lição vale para outros países.

A prospecção do potencial de empregos e auto-empregos no meio rural passa pelas seguintes etapas:

- avaliação dos empregos rurais não agrícolas que possam dar lugar a planos locais (municipais) de desenvolvimento;

- avaliação do potencial de emprego e auto-emprego de sistemas agropecuários familiares que combinam a policultura com atividades pecuárias, aqüicultura e produções agroflorestais, com especial destaque para sistemas com culturas perenes que atuam simultaneamente como sumidouros do carbono e a este título podem competir por financiamentos especiais ${ }^{30}$;

- em particular, avaliação do efeito multiplicador da renda auferida pelos trabalhadores do setor de agronegócios constituído pela grande agricultura mecanizada, pouco numerosos, porém bem remunerados (em particular empregos na construção civil e nos serviços);

- análise sistemática das relações entre os pequenos produtores rurais e as grandes agroindústrias, com vistas à transformação de situações adversariais em sinergias positivas mediante reformulação de contratos;

- organização dos pequenos produtores em cooperativas e promoção de pequenas agroindústrias;

- avaliação do potencial de empregos e de auto-empregos ligados à valorização dos resíduos agrícolas;

- avaliação do potencial de empregos e de auto-empregos voltados à gestão do meio ambiente, dos solos, águas e florestas; 
- por último, identificação de novas oportunidades de geração de empregos e de auto-empregos através da valorização das biomassas, tema que será tratado na próxima seção deste trabalho.

\section{Empregos e auto-empregos ligados à valorização das biomassas}

O Brasil possui a maior biodiversidade do mundo. Seu extenso território abriga ecossistemas variados, em sua maio ria dotados de recursos hídricos abundantes e de climas favoráveis à produção de biomassas as mais diversas. A maior floresta tropical do mundo está local izada na Amazônia brasileira. As reservas de solos passíveis de serem cultivados são cal culadas em dezenas de milhões de hectares, sem contar com a possibilidade de transformar em culturas os extensos pastos. Em outras palavras, a fronteira agrícola ainda pode avançar mantendo integralmente em pé as florestas intocadas conquanto sejam respeitadas as regras de manejo ecologicamente sustentável dos recursos naturais.

Por último, o país dispõe de uma base científica sólida nas áreas de agronomia e biologia que lhe permite avançar no caminho da revolução duplamente verde e da revolução azul ${ }^{31}$.

N enhum outro país do mundo reúne condições igualmente favoráveis à criação gradual de uma nova civilização sustentável dos trópicos, baseada na exploração sistemática do trinômio bi odiversidade-bi omassas-bi otecnologias, estas últimas aplicadas nas duas pontas para aumentar a produtividade das biomassas e abrir o leque dos produtos dela derivados.

As biomassas têm oito usos principais: alimentos, ração animal, bioenergia, fertilizantes, materiais de construção, matérias-primas industriais (fibras, celulose, óleos, resinas etc.), fármacos e cosméticos. $\mathrm{N}$ este elenco convém ressaltar as bioenergias que permitem a substituição das energias fósseis e que contribuem, portanto, para a luta contra o efeito estufa. 0 Brasil foi pioneiro em escala mundial com o seu plano Pro-álcool, e está longe de ter esgotado as suas potencialidades.

A identificação sistemática de novas oportunidades de aproveitamento de biomassas e a quantificação do número de empregos e de auto-empregos que poderão ser gerados constituem uma prioridade para o BN DES como ficou claro no seminário "A inclusão social pelo trabalho decente e o sistema defomento" promovido por este Banco em setembro de 2003, em cooperação com a ABDE ea O IT ${ }^{32}$.

U m passo importante nessa direção seria a confecção de um atlas seletivo de biodiversidade para as diferentes eco regiões do país, tarefa esta que os pesquisadores da E mbrapa estão dispostos a empreender ${ }^{33}$. D esde já podemos adiantar vários temas prioritários.

\section{Do Pro-álcool ao Pro-cana}

O Pro-álcool foi implementado como um programa de economia de guerra num breve lapso de tempo, sem que fossem observados os custos da operação. 
Ele permitiu ao Brasil reduzir a sua dependência com relação às importações de petróleo e provou ainda que a aditivação do álcool à gasolina não criava problemas no funcionamento dos motores de automóvel, em que pesem as restrições que, à época foram emitidas. Fundamentado numa aliança entre os grandes usineiros, as montadoras, as indústrias nacionais de equipamentos e o Estado autoritário, ele contribuiu para a concentração de terras e de capital, implantando quase todas as unidades de produção em São Paulo e no N ordeste.

A concentração espacial resultou num altíssimo custo de transporte do álcool através do subcontinente brasileiro. Provavelmente foi um erro autorizar a circulação dos carros movidos ao álcool no país inteiro, em vez de usar essa tecnologia para frotas de circulação restrita (viaturas de serviço público, transporte coletivo).

0 projeto de incentivar a construção de dezenas de milhares de micro e miniusinas para 0 abastecimento local em combustível e reduzir, desta maneira, o custo de distribuição do álcool foi encaminhado pelo M inistério da Indústria, mas nunca chegou a ser discutido pelo Congresso.

Por outro lado, fal tou um programa semelhante para a substituição parcial do óleo diesel por óleos vegetais, o que levou a uma situação insólita: o Brasil era obrigado a continuar a importar petróleo para atender à demanda pelo diesel, ficando com sobras de gasolina que eram vendidas no exterior a um preço muito baixo.

Por fim, todo o esforço foi concentrado sobre o álcool e o açúcar, dandose pouca atenção ao aproveitamento dos demais subprodutos da cana-de-açúcar, a começar pelo bagaço e pelo vinhoto. A sucro-química e a alco-química tampouco tiveram o desenvolvimento que se podia esperar.

Essas observações são importantes hoje, quando se fala em um eventual duplicação da produção do álcool para atender à demanda exterior, principalmente do J apão. Pensamos que essa duplicação poderá ocorrer sem repetir os erros do primeiro Pro-álcool e deveria se dar primordialmente através de implantação de micro e miniusinas no interior do país, aproveitando o potencial das grandes unidades já instal adas para a exportação.

O utrossim, esta é uma oportunidade para analisar a cadeia da cana com o intuito de sua racionalização e densificação em atividades econômicas anexas geradoras de emprego e de renda. Acreditamos que essa cadeia proporciona oportunidades de criação de empreendimentos de pequeno porte, cooperativos ou privados, para aproveitar melhor a palhagem, o bagaço ${ }^{34}$, o vinhoto (tratado no biodigestor) e as proteínas recuperadas das águas de lavagem. Como já foi dito, existe ainda um vasto campo para a diversificação dos produtos derivados do açúcar e do álcool, a começar pela exportação de produtos como o chocolate, em vez do açúcar e do cacau.

U m projeto voltado para esses problemas está sendo organizado no Estado de Pernambuco, numa parceria do Sebrae-PE, Sebrae-N acional e a Confederação Pernambucana das I ndústrias. Seria bastante interessante se a esse projeto fose e implementado no Estado de São Paulo. 


\section{Pro-óleo}

O governo lançou recentemente o Programa Brasileiro de D esenvolvimento Tecnológico de Biodiesel (Probi odiesel) e o presidente da República inaugurou em Piracicaba o Pólo Nacional de Biocombustíveis, que funcionará na EsalqU SP. J unto com o L aboratório de D esenvolvimento de Tecnologias L impas ( $L$ adetel), este polo vai desempenhar um papel importante na formulação e implementação do Probiodiesel.

O L adetel está atualmente trabal hando sobre onze variantes de óleos vegetais que podem servir de aditivo ao diesel: soja, amendoim, girassol, algodão, milho, canola, mamona, pequi, macaúba, babaçu, dendê, além de óleos de recuperação utilizados para fritura nos restaurantes. A U FPE concentra seus estudos sobre o de soja.

A parentemente, todos esses estudos têm um cunho técnico que privilegia a produtividade e os custos. Pensamos que a avaliação das diferentes opções para a aditivação de óleos ao diesel deveria ser objeto de uma avaliação mais ampla, incluindo critérios sociais e ambientais, além de considerações de estratégia de desenvolvimento regional. Senão, corremos o risco de que o biodiesel venha a ser mais um fator de expansão da cultura de soja, inclusive em áreas ambientalmente pouco adaptadas para este tipo de cultivo, e que se perca assim a oportunidade de gerar um número mais elevado de empregos e auto-empregos pela escolha de plantas que proporcionam maior oferta de ocupação e se enquadram melhor em sistemas policulturais da agricultura familiar. Do ponto de vista ambiental, um critério essencial para o N ordeste semi-árido é a escolha de plantas que requerem pouca água (enquanto a Amazônia deveria se especializar em culturas aqüívoras).

A Agência U SP de I novação Tecnológica que está sendo formada poderia servir de ponto focal para a avaliação abrangente dos óleos vegetais candidatos ao Probiodiesel em cooperação com a E mbrapa. O Sebrae e a ABD E (que representa o sistema de fomento) constituem, a nosso ver, parceiros potenciais neste empreendimento na medida em que estão interessados em identificar, promover e viabilizar, do ponto de vista da arquitetura financeira, os empreendimentos de pequeno porte que possam surgir ao longo da cadeia de produção de óleos vegetais desde o campo até a fase de processamento. Este poderá ocorrer em unidades pequenas, de preferência cooperativas, ou dar ensejo a uma integração dos pequenos produtores de biomassa com agroindústrias de porte maior. Convém lembrar aqui o conceito de refinarias de biomassas formulado pelo agrônomo indiano M. S. Swaminathan, que se encarregariam da primeira fase de processamento de maneira a reduzir o volume do semiproduto encaminhado para unidades industriais de grande porte.

O Probiodiesel prevê por enquanto a aditivação de $5 \%$ de óleo vegetal ao diesel. Tudo indica que este percentual poderá aumentar significativamente, a exemplo do que aconteceu com a mistura do álcool com a gasolina, proporcionando inúmeras perspectivas para o cultivo das plantas oleaginosas.

0 estudo dos óleos vegetais não se deve restringir aos seus usos energéticos. o Brasil está atualmente importando'óleos vegetais, em particular o óleo de 
dendê, para consumo humano. Este potencial de substituição de importações merece figurar alto na lista das prioridades.

A cultura do dendezeiro (originário da África e amplamente difundido na Ásia) encontra um ambiente favorável em várias áreas da A mazônia e na Z ona da $M$ ata da Bahia. Estudos indicam que, no mercado mundial o óleo de dendê é cada vez mais procurado. 0 seu cultivo é bastante intensivo em mão-de-obra. D ez hectares de dendê requerem um trabalhador em tempo integral durante 0 ano todo. Como se trata de uma cultura perene, a plantação funciona como um sumidouro do carbono. $\mathrm{N}$ a M alásia, as plantações de dendê serviram de base para a reforma agrária.

No contexto brasileiro, a pedido do governo do A mapá, chegou a ser elaborada, no ano 2001, (porém não implementada) uma proposta de assentamentos de reforma agrária para ocupar terras já desmatadas da Amazônia com plantações de dendezeiro, à razão de dez hectares para cada família assentada, complementados por outros dez hectares para cultivos de subsistência e agroflorestai $s^{35}$. Entendimentos mantidos na época com uma grande empresa nacional especializada na produção do óleo de dendê indicaram a sua disposição em colocar uma usina de processamento conquanto o assentamento tivesse uma área de cinco mil hectares cultivados em dendê. A empresa se encarregaria de oferecer as mudas, daria a assistência técnica aos assentados e assinaria um contrato de compra exclusiva dos cachos de dendê a um preço estipulado em percentual do preço mundial do óleo dendê. Tudo indica que um assentamento desse tipo, além das inegáveis vantagens ambientais (recuperação dos solos, seqüestro do carbono) proporcionaria aos assentados de três a quatro ocupações com rendimentos decentes por família, contando os empregos agrícolas, as atividades de subsistência, os empregos na fábrica, no transporte, nos serviços técnicos, sociais, administrativos e pessoais, além do comercio local. U m assentamento de quinhentas famílias se transformaria, em poucos anos, numa próspera vila agro-industrial.

0 projeto suscitou grande interesse por parte das autoridades federais, porém, devido a determinadas circunstâncias, não saiu do papel. Ele pode servir, no entanto, de protótipo para projetos de reforma agrária e de desenvolvimento rural sustentável e integrado, construídos ao redor de um cultivo perene. Como já foi dito, extensas áreas da Amazônia legal prestam-se à implementação dos projetos dendê.

\section{Madei ra efibras}

U m outro componente do complexo agro-bio-industrial a ser cuidadosamente estudado focalizando a articulação dos produtores familiares com a grande indústria é o da produção da madeira, com especial destaque para quatro temas:

- as florestas familiares (a serem preferidas às Fonas) e o seu encadeamento com as madeireiras na Amazônia;

- integração do plantio de eucaliptos e outras espécies para celulose nos projetos de desenvolvimento rural integrado e sustentável; 
- produção de fibras vegetais com potencial de aproveitamento industrial inovador (por exemplo, uso de fibras vegetais na construção de automóveis);

- diversificação de materiais de construção de origem vegetal (bambú, fibras etc.).

\section{0 potencial da revolução azul}

A revolução azul, ou seja, a passagem da caça e coleta de espécies aquáticas e anfíbias para a sua criação e cultivo encontra-se ainda numa fase incipiente, porém, de crescimento rápido em termos mundiais. Em 1970, a piscicultura respondia por apenas 3,9\% da produção total do pescado. Este percentual subiu para $27,3 \%$ no ano 2000.

N o Brasil, a indústria do camarão tem crescido à taxa de $50 \%$ ao ano, e devia alcançar, em 2003, noventa mil toneladas cultivadas sobre catorze mil hectares de tanques, alcançando uma produtividade excepcionalmente alta de 6,4 toneladas por hectare e gerando cerca de 48 mil empregos diretos. N a Tailândia, um dos líderes deste mercado com 260 mil toneladas em 2002, a produtividade é de 3,4 toneladas/ ha/ ano ${ }^{36}$. Estima-se que foram exportados cerca de U S\$ 240 milhões em 2003, o que confere no N ordeste à indústria do camarão o segundo lugar na exportação depois do açúcar. Infelizmente, surgem fortes críticas com relação aos impactos ambientais desta atividade. O s exemplos de Equador e das Filipinas servem de exemplo para sinalizar os perigos daí decorrentes. Por outro lado, os pequenos produtores queixam-se de um padrão insatisfatório de relacionamento com as grandes empresas no ramo que cobram taxas excessivas pela administração e assistência técnica, porém, nas condições atuais, constituem o indispensável elo intermediário para alcançar os mercados ${ }^{37}$.

A piscicultura foi responsável em 2003 pela produção de 120 mil toneladas. Entre as espécies nativas de peixes, poucas são ainda as cultivadas em escala comercial, apesar de excelentes qualidades gustativas: tambaqui, pacu, jundiá e matrichã38. 0 potencial brasileiro para aqüicultura marinha e em águas continentais é excepcional. $\mathrm{N}$ ão há razão para que os peixes não passem a constituir uma fonte importante de proteína animal na dieta dos brasileiros. A introdução da piscicultura nos sistemas integrados de agricultura familiar pode contribuir decisivamente para sua maior rentabilidade ${ }^{39}$.

\section{E mpregos nos setores não comerciáveis da economia}

Como já foi dito, por não estarem submetidos à competição internacional, os setores de produção de bens e serviços não comerciáveis deixam uma maior margem de liberdade para a escolha de tecnologias. Em vez de aceitar os padrões dos países mais avançados, é possível lançar mão de tecnologias de menor intensidade de capital. É claro que se deve estipular para cada país e momento a produtividade de trabalho mínima abaixo da qual não faz sentido descer. Convém sempre ter presente a diferença entre estratégias de mera sobrevivência - logradas muitas vezes mediante um esforço extenuante, porém de baixíssima produtividade - e estratégias de desenvolvimento que implicam um piso de produtividade além do seu contínuo aumento. 
Com essas ressal vas pensamos, que nas condições brasileiras, existem consideráveis reservas de emprego condicionadas por uma escolha mais criteriosa das tecnologias nos setores de produção de não comerciáveis, que passamos a comentar brevemente.

\section{Osserviços sociais mi ni strados pelas redes de educação, saúde pública easis stência social}

Paradoxalmente, os países pobres deveriam carregar a sua função-objetivo com os serviços desta natureza enquanto o nível geral de salários permanece baixo, em vez de postergar o desenvolvimento social para uma fase ulterior do seu crescimento. O s professores primários, para citar um exemplo, são tão "produtivos" nos países pobres quanto nos países ricos: nos dois casos, o professor toma conta do mesmo número de alunos. Porém o seu custo é bem inferior nos países pobres, que por assim dizer, gozam de vantagens comparativas nas atividades intensivas em mão-deobra qualificada, que exigem investimento módico por posto de trabalho criado. Em outras palavras, o desenvolvimento social não deve esperar pelo desenvolvimento econômico e a seqüência histórica seguida pelos países industrializados deve ser invertida ${ }^{40}$.

Pelo fato de contribuírem diretamente para o bem-estar da população, a universalização do acesso aos serviços sociais afigura-se como uma componente essencial do tripé de desenvolvimento includente, sustentável e sustentado. Em que pesem as investidas dos economistas neoliberais contra a hipertrofía do aparelho do Estado, a demanda por serviços sociais está longe de ser saturada, inclusive nos países mais ricos do planeta. 0 escopo, o volume e a qualidade destes serviços oferecem numerosas oportunidades de emprego e um campo de atuação para organismos públicos, O ccips, e diferentes parcerias entre o público e 0 privado (PPP). Sem dúvida, as administrações pletóricas devem ser reduzidas, ao passo que o número de agentes dos serviços so ciais aumenta. D esde 1997, a G rãB retanha criou quinhentos mil empregos adicionais nos serviços públicos, ou seja, a metade de todos os empregos gerados.

\section{Ser vi ços, comér ci o, turi smo}

Pela facilidade de entrada, os serviços domésticos e o comércio ambulante (camelôs, sacoleiras) são as atividades que hoje abrigam grande contingentes pletóricos da mão-de-obra em busca de estratégias de sobrevivência. Essas ocupações precárias e mal remuneradas funcionam como a válvula de segurança do capitalismo selvagem.

$\mathrm{N}$ a maioria dos casos, sua desinformalização e transformação gradual em trabal ho decente será acompanhada da redução dos efetivos. Em compensação, há espaço para expandir serviços técnicos e pessoais em forma de ocupações decentes para trabalhadores por conta própria, cooperativas de serviços e micro e pequenas empresas.

O s serviços de manutenção merecem um comentário. A boa manutenção do estoque existente de equipamentos, das infra-estruturas, do parque imobilário 
e viário, resulta numa prorrogação de sua vida útil e, portanto, na redução da demanda pelo capital de reposição. Ceteris paribus, isto significa uma disponibilidade maior de capital para investimento líquido. Trata-se, portanto, de uma importante e subestimada alavanca de desenvolvimento.

0 mesmo pode ser dito de atividades que poupam os recursos naturais, mediante conservação de solos, água e energia, reciclagem do lixo e dos materiais e aproveitamento dos resíduos agrícolas etc. Elas resultam numa maior produti vidade dos recursose, portanto, contribuem para a um maior crescimento do PIB. Trata-se de um conjunto de atividades intensivas em mão-de-obra e que deveria ser objeto de um cuidado especial, tanto mais que elas contribuem para sustentabilidade ecológica do processo de desenvolvimento.

A absorção da mão-de-obra pelo setor de turismo vai depender do modelo adotado. Parece-nos que o potencial de atração do Brasil para turistas estrangeiros endinheirados está sendo sobreestimado. A competição internacional nese setor de serviços já é acirrada e os investimentos em redes de hotéis de luxo são muito dispendiosos. No entanto, o turismo interno de massas e a organização de colônias de férias para trabalhadores e escolares não estão recebendo a devida atenção.

O sucesso dos rodeios como os de Barretos, por exemplo, aponta para o efeito indutor de festas populares, festivais, cerimônias religiosas, espetáculos artísticos e esportivos, além do carnaval. 0 verdadeiro turismo ecológico (denominação usada hoje abusivamente) nunca poderá ser de massas, mas está se impondo como um ramo de atividades a ser integrado nas estratégias de desenvolvimento local de numerosas micro-regiões.

\section{A construção civil com especial destaque}

\section{para a construção de moradi as de manei ra a reduzi r}

\section{o défi cit calculado em vári os mi l hões de uni dades habi taci onais}

Trata-se de uma indústria na qual as tecnologias intensivas em mão-deobra encontram ainda um vasto campo de aplicação que poderia ser ainda mais ampliado ao se lançar mão da inclusão de cláusulas apropriadas nos termos das licitações públicas e nos contratos de financiamento por bancos públicos. Pensamos que os bancos públicos e o sistema de fomento podem desempenhar um papel relevante no redirecionamento das tecnologias para produção de bens não comerciáveis.

A tradição do muti rão está arraigada na cultura brasileira. D aí o interesse em promover grandes programas de construção de moradias populares por meio de mutirão assistido, ou seja, devidamente enquadrado por assistência técnica, dispondo de créditos para a aquisição de materiais de construção por parte dos futuros moradores e provido com terrenos viabilizados. Convém observar que o trabaIho fornecido pelos futuros moradores constitui uma forma de poupança não monetária, aumentando ceteris paribus o volume do investimento realizado no país.

\section{As obras públicas}

Como a construção civil, as obras públicas permitem escolher tecnologias de grande intensidade em mão-de-obra, conquanto se respeite um limite míni- 
mo de produtividade de trabalho, abaixo do qual as frentes de trabal ho passam a constituir uma política assistencial e não mais um instrumento de política econômica.

Entre as obras públicas destacam-se aquelas que têm um retorno rápido, tais como construção de cisternas no N ordeste, de pequenos perímetros de irrigação, de estradas vicinais, de calçamento de ruas etc. 0 saneamento foi reconhecido a justo título como uma prioridade.

Acreditamos que 0 volume de obras públicas pode ser grandemente expandido ao se dar uma interpretação menos restritiva ao conceito de responsabilidade fiscal. $\mathrm{N}$ ão há razão para pensar que um afrouxamento de créditos para essas obras resulte numa pressão inflacionária conquanto a agricultura e a indústria brasileiras sejam capazes de enxugar a demanda adicional por bens de salário com uma oferta elástica destes bens a preços estáveis.

A participação de cooperativas de trabalho genuínas, devidamente fiscalizadas no que diz respeito às leis trabalhistas e previdenciárias, é recomendada fortemente, podendo se dar em forma de contratos diretos ou de subcontratação por empreiteiras.

M ais uma vez, convém lembrar o papel que os bancos públicos e o sistema de fomento podem desempenhar na promoção de tecnologias apropriadas ${ }^{41}$.

\section{Indústrias naturalmente intensivas em mão-de-obra e artesanato}

Ao contrário do setor de produção dos não comerciáveis, as indústrias naturalmente intensivas em mão-de-obra (têxtil, confecções, sapatos, móveis etc.) estão expostas a uma competição internacional acirrada, já que quase todos os países menos desenvolvidos apostam nesse nicho do mercado. 0 que está acontecendo no mercado de calçados, por exemplo, é emblemático. As grandes empresas multinacionais que controlam o acesso ao mercado de países industrializados deslocam a sua produção para as zonas francas dos países que oferecem 0 menor custo de produção, ou seja, salários extremamente baixos, longas jornadas de trabal ho, e isenções de impostos e taxas alfandegárias, a começar pela C hina ${ }^{42}$.

A termo, essa competição selvagem gera, para países como o Brasil, problemas tão graves quanto o protecionismo dos países industrializados com respeito aos produtos agrícolas. $\mathrm{D}$ aí a importância de se colocar este tema na pauta das negociações entre os membros do recém-formado G-3 (B rasil, Í ndia e África do Sul) e G-20.

Paralelamente é preciso envidar esforços para racionalizar essas indústrias de maneira a garantir a sua parcela do mercado interno. E ssa racional ização passa pelo fortalecimento dos poucos APL s hoje existentes e pelas políticas de apoio à emergência e consolidação de novos APL s, em outras palavras, pela rearticulação das relações entre grandes empresas e empreendimentos de pequeno porte, e pela promoção das mais variadas formas de empreendedorismo coletivo a montante (serviços técnicos, treinamento da mão-de-obra, design, compras coleti- 
vas) e a jusante (comercialização). D eve-se contemplar ainda a criação de bancos de APLS.

Em que pese a competição internacional, o Brasil tem condições para identificar nichos de exportação em certos ramos de confecção (roupas de praia) e indústria de móveis, esta última favorecida pela abundante oferta de madeiras de lei e de couros.

Várias regiões do Brasil possuem um artesanato artístico de qualidade, por enquanto insuficientemente conhecido no mundo e pouco utilizado pelas redes nacionais de hotéis e restaurantes, um mercado institucional potencialmente grande. Ao mesmo tempo, é preciso tomar cuidado para que esse artesanato não seja desnaturalizado através de uma produção de massa de pacotilha, como aconteceu em países que têm uma grande tradição de artesanato artístico como a Í ndia ou o M éxico.

Pensamos que 0 artesanato artístico deveria ser objeto de um programa abrangente: criação de escolas vocacionais, bolsas para artistas populares, concursos anuais com numerosos prêmios de aquisição (uma maneira de constituir um acervo de peças para museus e exposições itinerantes), intermediação entre os artesãos e os mercados institucionais, promoção do artesanato artístico brasileiro no exterior.

\section{Empreendimentos de pequeno porte}

D evido ao seu grande peso na estrutura de empregos e de auto-empregos, a consolidação, expansão e geração de empreendimentos de pequeno porte deve ocupar um lugar de destaque na estratégia de inclusão social pelo trabal ho decente. 0 relatório já citado do Sebrae-Pnud mostrou a enorme heterogeneidade deste setor da economia, e a conseqüente necessidade de desenhar políticas diferenciadas para os seus diferentes segmentos:

- os trabalhadores por conta própria que se subdividem em duas categorias bem distintas, os empenhados em atividades de baixa qualificação (vendedores ambulantes, sacoleiras, prestadores de serviços domésticos e pessoais etc.) e os prestadores de serviços profissionais altamente qualificados;

- micro e pequenas empresas com atividades informais;

- micro e pequenas empresas atuando na economia formal;

- trabalhadores por conta própria, micro e pequenas empresas pertencentes ao setor cooperativo, às entidades sem fim lucrativo e demais formas de economia solidária.

D e uma maneira geral, o que caracteriza os empreendimentos de pequeno porte é o reduzido custo em capital de entrada na atividade. 0 coeficiente capital/ trabalho (i) é baixo (com a exceção de certos serviços profissionais que requerem equipamentos de alta tecnologia). Porém, a contraparte de um i módico é constituída por um coeficiente baixo produto/ trabalho (p), ao ponto de acar- 
retar, em muitos casos um coeficiente alto de capital/ produto $(k)^{43}$. O s três coeficientes estão ligados pela identidade: $i=k p$.

A maioria dos pequenos empreendedores é obrigada, pela baixa produtividade do seu trabalho, a buscar a competitividade por meio de expedientes conhecidos como fatores de competitividade espúria: baixos salários, ausência de proteção social, longas jornadas de trabalho, sonegação de impostos, condições de trabal ho insalubres. Em outras palavras, para enfrentar osrigores do darwinismo social no mercado eles não têm outra solução a não ser mergulhar na informalidade. Os próprios interessados são as primeiras vítimas do trabalho precário, porém, a sociedade toda sai perdendo. 0 Estado deixa de arrecadar, ao mesmo tempo, a luta contra a pobreza sob forma de ações focal izadas assistenciais drena recursos que devem ser desviados de investimentos direcionados à inclusão social pelo trabalho decente.

Por isso consideramos que a desinformalização dos empreendimentos de pequeno porte e o aumento contínuo da sua produtividade de trabalho constituem as prioridades máximas nas políticas voltadas para esse setor da economia. Ao mesmo tempo, é necessário consolidar as M PEs existentes e diminuir os altos índices de mortalidade observados atualmente. A concentração dos esforços na promoção de novos empreendimentos fadados a desaparecer em meses ou em poucos anos, assemelha-se a um trabal ho de Sísifo. Por último, deve-se pensar na expansão das empresas de pequeno porte existentes e, sempre que possível, sua graduação para a categoria de médias empresas ${ }^{44}$.

A saída da informalidade requer um conunto de políticas públicas complementares inspiradas pelo princípio de tratamento desigual dos desiguais, no caso, ações afirmativas em favor dos empreendedores mais fracos, para que possam, com o tempo, enfrentar o mercado em condições de competitividade genuína e de produtividade suficiente para proporcionar postos de trabalho decente.

Listamos a seguir as políticas que se fazem necessárias:

- a desburocratização do processo de criação de novos empreendimentos (micro e pequenas empresas, cooperativas, consórcios, associações de produtores etc.), em outras palavras, um Fácil mais fácil, mais abrangente e mais barato;

- um regime fiscal com alíquotas mais baixas, ou seja, um Simples mais abrangente, incluindo os impostos federais, estaduais e municipais;

- um Simples previdenciário;

- acesso amplo a créditos preferenciais;

- acesso aos mercados, por meio de um regime preferencial nas compras públicas e licitações de obras públicas ${ }^{45}$;

- acesso às tecnologias apropriadas, que provavelmente vai exigir a criação de um serviço de extensão análogo aos serviços de extensão rural;

- promoção de todas as formas empreendedorismo coletivo, o mais importante instrumento de fortalecimento de pequenos empreendedores no 
enfrentamento do mercado como compradores, vendedores e fornecedores de bens e de serviços com especial destaque para a consolidação dos Arranjos Produtivos $L$ ocais existentes e emergentes; este é um campo de atuação para instituições como o Sebrae, os sindicatos, a O IT, a O CB e as incubadoras da economia solidária que estão surgindo em várias universidades;

- racionalização da articulação entre as grandes empresas e os empreendimentos de pequeno porte, de maneira a amenizar as relações adversárias, promovendo, na medida do possível, sinergias positivas (subcontratações, terceirizações, integração nas agroindústrias, franquias etc. ${ }^{46}$, e logrando a necessária complementaridade entre a expansão do núcleo modernizador da economia e o universo dos empreendimentos de pequeno porte.

A proveitando 0 atual debate sobre a reforma tributária, o Sebrae nacional está empenhado em promover uma autêntica lei áurea das MPEs, integrando a maioria das políticas enumeradas acima. D evido à variedade de configurações, 0 estudo empírico das saídas da informalidade requer um grande número de estudos de caso, tanto nas regiões metropolitanas como em aglomerações de menor porte.

A implantação da estratégia de combate à pobreza pela Secretaria do D esenvolvimento, Trabalho e Solidariedade da Prefeitura de São Paulo47, a atuação do Sebrae-SP na Zona Leste de São Paulo e a próxima criação de um observatório social e econômico dessa região no novo campus da U SP criam condições favoráveis para um estudo da maior concentração da pobreza metropolitana no Brasil.

D evemos entender melhor os determinantes do comportamento dos informais confrontados com o dilema de permanecer nas atividades informais ou sair delas rumo a uma microempresa (muitas vezes unipessoal) ou ainda a uma cooperativa. Para tanto, deve-se levar em conta a complexidade da economia real urbana onde se entrelaçam quatro modos de produção (fora do mercado, protocapitalista, capitalista e solidário) com os bens e serviços distribuídos em quatro circuitos (a economia doméstica, a economia popular atendendo as populações de baixa renda, os demais setores da economia de mercado e as compras públicas). Contrariamente a um preconceito presente na literatura do tema, não existem duas economias separadas - a formal e a informal - e sim atividades formais e informais entrelaçadas. A economia popular, longe do constituir o apanágio exclusivo de artesãos e produtores protocapitalistas ${ }^{48}$ locais, é objeto de uma intensa competição entre os empreendedores de pequeno porte, as multinacionais cujos produtos ali chegam através de supermercados e de redes especialmente criadas de revendedores, enfim os produtos contrabandeados duplamente competitivos por não pagarem nenhuma taxa e por terem sido produzidos em países que não hesitam em promover as suas exportações recorrendo à competitividade espúria. Q ue impacto terão nestas condições as políticas discutidas acima? 
O s obstáculos à saída da informalidade apresentam-se sob uma luz diferente num caso como o do pólo de confecções do Agreste Pernambucano, que emprega aproximadamente 76 mil pessoas em doze mil unidades produtivas, das quais $8 \%$ apenas são formais. A produção é de 57 milhões de peças por mês, com um faturamento mensal superior a R \$ 144 milhões. Q uase toda a produção é escoada através das três grandes feiras semanais realizadas às segundas em $C$ aruaru, às terças em Toritama, e às quartas em Santa Cruz do C apibaribe com a presença de cerca de 45 mil compradores, transportados por ônibus especiais ${ }^{49}$.

Trata-se de uma forte concentração geográfica de indústrias de confecção que atualmente não tem semelhança alguma com o tão atrativo modelo de Arranjos Produtivos L ocais encontrado na Terza I tália. A feição essencial dos APLs é a presença simultânea de competição e cooperação entre os produtores. 0 que mais falta no pólo do Agreste Pernambucano é a cooperação. A competição é extremamente acirrada e os pequenos produtores locais enfrentam as empresas de grande porte que as abastecem de tecidos e de aviamentos e que vendem 0 maquinário, além de encontrarem dificuldade para escoar os seus produtos por um método mais eficiente do que a colportagem por sacoleiras. Para completar o quadro, os produtores locais se queixam da concorrência de produtos chineses que alí chegam a um preço menor do que os custos de produção locais. É possível fazer evoluir o pólo de confecções do Agreste para que se torne um APL? Q ue políticas seriam necessárias para isso?

\section{E mpreendimentos de pequeno porte de alta tecnologia}

A importância dos empreendimentos de pequeno porte de alta tecnologia para o desenvolvimento é indiscutível, embora o seu potencial de geração de empregos seja diminuto. As M PEs desse tipo complementam a produção do núcleo modernizador e desempenham uma função extremamente útil na interface entre a pesquisa académica e 0 setor produtivo, e as incubadoras de empresas hightech junto às universidades constituem um instrumento eficaz de sua promoção.

É verdade que a expansão de serviços baseados nas novas tecnologias de informação e comunicação (NTIC) poderia impactar o mercado de trabalho, caso o Brasil pudesse se posicionar favoravelmente nos mercados internacionais, o que não nos parece ser o caso. A tendência mais provável será um aumento de emprego nesse tipo de serviços ( não necessariamente em micro e pequenas empresas) que não será suficiente para compensar as reduções de emprego nos bancos e escritórios. A terciarização se traduz por uma transferência e não uma criação de empregos adicionais.

Em conclusão, pensamos ter demonstrado que o Brasil tem potencial para se transformar de modo aproximado em uma "fábrica de empregos decentes" . A tarefa mais urgente é quantificar aproximativamente 0 tamanho dos diferentes 
nichos de oportunidades aprofundando, ao mesmo tempo, a discussão sobre os obstáculos que devem ser removidos e as políticas públicas que se fazem necessárias. Sugere-se que o M inistério do Trabalho promova esse estudo, valendo-se do acervo de dados acumulados pela O IT para estimar o custo dos diferentes empregos, o conteúdo em divisas dos investimentos propostos, a capacidade de gerar poupança adicional pelos mutirões, e oferecer assim um subsídio importante para a elaboração de estratégias locais e regionais de desenvolvimento. Pela abrangência do estudo, o M inistério do Trabalho, iniciador e gestor do projeto, deverá buscar parcerias com vários outros M inistérios, com o BNDES, o I pea, a Finep, a E mbrapa, a CN I e o Sebrae, bem como a O IT, o PNU D e a Cepal.

N otas

10 Brasil vende $29 \%$ de todo o açúcar, $28,5 \%$ do café em grão e $43,6 \%$ do café solúvel consumidos no mundo. Assumiu a liderança em vendas de carne bovina em 2003, com 19\% de participação no mercado mundial. É o primeiro em vendas de carne de frango, com exportações da ordem de 1,9 bilhão de dólares, detém 38,4\% do mercado mundial de soja em grão, vende $23,1 \%$ do tabaco consumido no mundo e $81,9 \%$ do suco de laranja (Veja, 14 jan. 2004).

2 No dizer de Antônio Ermírio de M oraes, presidente do conselho de administração do grupo Votorantim, juros mais impostos mais burocracia é igual a economia informal. $70 \%$ da economia é informal hoje (entrevista concedida a Carta Capital, oo 272, 24 dez. 2003).

3 A taxa de desemprego aberto é de $12,4 \%$ e, portanto supera a média latino-americana de $11 \%$ Segundo os dados da O IT, o desemprego afeta na América L atina e no Caribe, dezenove milhões de pessoas, dos quais dez milhões de brasileiros ( 0 Globo, 8 jan. 2004). Porém, num país como o Brail, o trabalho precário e o sub-emprego constituem um desafio ainda mais grave, a menos de considerar que a informalidade seja uma solução e não um grave problema.

40 Estado de S. Paulo, 26 out. 2003.

$5 \mathrm{D}$ avid de Ferranti e Vinod Thomas, "A N ew M odel of G rowth - Why Eyes are on Brazil", I nternational H erald Tribune, 24-25 dez. 2003.

6 L. Rodigues, “Resultado de um ano de retratação”, 0 Globo, 24 jan. 2004.

7 Todos esses dados foram citados em Fátima Fernandes, "L iberalização à brasileira”, Folha deS. Paulo, 18 jan. 2004.

80 discurso de ano novo do presidente Chirac na França bateu na mesma tecla.

9 Em cinco anos, os Estados U nidos perderam 2,9 milhões de empregos em indústrias (LeM onde, 15 jan. 2004).

100 deslocamento abarca as indústrias tradicionais intensivas em mão de obra (vestuário, calçados, montagem de aparelhos eletrônicos etc.), dá origem às atividades de maquiladoras e, cada vez mais, atrai para países como a êndia os serviços baseados nas tecnologias modernas de informação e comunicação pertencentes à categoria de 
intensivosem mão-de-obra qualificada. Para o Brasil, coloca-se o problema de competição nos mercados externos, mas também no mercado brasileiro, com produtos fabricados em países que não hesitam em lançar mão da competitividade espúria, a começar pela China.

11 Veja-se, por exemplo, o artigo do ex-presidente Fernando H enrique Cardoso “Ano bom? Tomara” (O Globo, 4 jan. 2004): “O s governos também costumam ser considerados culpados pelas taxas de desemprego. $\mathrm{H}$ oje, no Brasil, elas batem recordes históricos. $\mathrm{N}$ as condições tecnológicas atuais, o crescimento do PIB precisa ser espetacular (no caso, cabe a qualificação) para ter efeito significativo sobre o desemprego".

12 Veja-se, I gnacy Sachs, I nclusão social pel o trabalho - desenvol vimento humano, trabaIho decentee o futuro dos em preen dedores de pequeno por te, relatório patrocinado pelo Sebrae e pelo PN U D, Rio de J aneiro, G arammond, 2003. Veja-se também a reportagem sobre o seminário "A inclusão social pelo trabalho decente e o sistema de fomento", realizado no BNDES em setembro de 2003, R umos, ano 27, № 211, set.-out. 2003.

13 Rubens Ricúpero, Folha deS. Paulo, 31 ago. 2003.

14 D eve-se ao economista chileno A nibal Pinto, um dos principais pensadores cepalinos, a definição do desenvolvimento como superação da heterogeneidade social.

15 Sobre o conceito de desenvolvimento includente, ver I. Sachs, D esen volvimento indudenteetrabalho decente para todos, documento preparado para a Comissão M undial sobre a D imensão Social da Globalização, O IT, out. 2002; editado em português pela O IT-escritório no Brasil.

16 Ver a respeito, I. Sachs, "E conomia política do desenvolvimento Segundo Kalecki: crescimento puxado pelo emprego", em L. Pomeranz, J. M iglioli, e G. Tadeu Lima (orgs.), Dinâmica econômica do capitalismo contemporâneo ( homenagem a $M$. K alecki ), Edusp/ Fapesp, São Paulo, 2001, pp. 269-288.

17 U ma vez controladas as doenças endêmicas, o trópico passa a ser uma vantagem natural como intuiu Gilberto Freyre ao lançar o conceito de "tropicologia". Ver a respeito I. Sachs, "D os tristes trópicos aos trópicos alvissareiros", em Carvalheira C unha, L. e Vila N ova S. (orgs. ), D ostristestrópi cosaos trópi cosalvi ssarei ros, Recife, Fundação J oaquim N abuco / M assangana, 2002, pp. 23-69.

18 A produção de hortigranjeiros requer pelo menos cem vezes mais trabalhadores por hectare do que a de grãos altamente mecanizados, por sua vez, a floricultura absorve quinze vezes mais trabalhadores por hectare do que os hortigranjeiros. As culturas perenes como o café e o cacau são três a quatro vezes menos intensivas em mãode-obra, do que os hortigranjeiros. Infelizmente, não se pode transformar em floricultura os cem milhões de hectares de terras cultiváveis ainda disponíveis no Brasil. E $m$ trabalho recente, J osé Eli da Veiga, afirma que na agricultura brasileira, treze lavouras devoram postos de trabalho: cana-de-açúcar, café, laranja, algodão, milho, cacau, alho, banana, côco-da-bahia, maçã, mandioca, tomate rasteiro e trigo. Porém, outras dez são capazes de aumentar a oferta de ocupação: amendoim, arroz, caju, feijão, malva, mamona, sisal, soja, uva e tomate envarado. O utrossim, grandes quantidades de mão-de-obra podem ainda ser absorvidas pela fruticultura em plena 
expansão e as produções de borracha, chá, dendê, erva-mate, ervilha, fava, palmito e urucum, além da intensa osmose que prevalece entre a policultura desses vegetais e atividades pecuárias. 0 Brasil dispõe de um imenso mosaico de sistemas produtivos diversificados, cuja essência é a sinergia agropecuária. (Valor econômico, 12 ag. 2003, artigo reproduzido em Estudos A vançados, U SP, 17 (48) 2003).

190 conceito de tecnologiasapropriadasé mais amplo que o de tecnol ogiasinter mediárias advogadas por Schumacher no seu celebrado livro Small is Beautiful. As tecnol ogiasapropriadassão aquelas que respondem ao conjunto de critérios adotados para sua avaliação. Estes, no nosso entender, não se devem limitar a critérios puramente técnicos, e sim incluir critérios sociais (geração de empregos decentes) e ambientais.

As tecnologias híbridas constituem um caso particular de tecnologias apropriadas, combinando, por um lado, o saber moderno com o tradicional (episteme com techne) e, por outro lado, aplicando tecnologias de diferentes intensidades em mão de obra nos diferentes el os de uma cadeia de produção. O s casos mais interessantes ocorrem quando o uso catalítico de tecnologias de ponta num elo viabiliza o recurso a tecnologias intensivas em mão-de-obra nos demais elos da cadeia. Isto acontece com freqüência nas cadeias de valorização da biomassa, mediante a aplicação de biotecnologias que abrem o leque dos produtos dela derivados.

20 M. Kalecki introduziu o conceito de período de reestruturação (retooling period). Se uma inovação tecnológica abrange a cada ano um décimo do aparel ho de produção existente no país, o período de reestruturação será de dez anos. A modulação deste parâmetro pode ser objeto da política industrial.

21 Abordei esse tema em três trabalhos recentes. Ver I. Sachs: "Brasil rural: da descoberta à invenção" em EstudosA vançadosno 15 (43), 2001, pp. 75-82; "U m projeto para o Brasil: a construção do mercado nacional como motor do desenvolvimento" em L. C. Bresser Pereira e J. M. R ego (orgs.), A grandeesperança em C el so Furtado, Ed. 34, São Paulo, 2001, pp. 45-52; "Q uo Vadis Brasil” em I. Sachs, J. Wilheim, e P. S. Pinheiro (orgs.), Brasil, um século detransformações, São Paulo, Cia das L etras, 2001, pp. 488-501.

22 O s trabalhos de José Eli da Veiga mostraram que o grau de urbanização real do Brasil é inferior às estatísticas do IBGE: nos 4,5 mil municípios rurais viviam no último ano do século passado, quase 52 milhões habitantes (J osé Eli da Veiga, Cidades imaginárias - o Brasil é menos urbano do que se calcula, Campinas, Autores Associados, 2002).

23 Em questão, no 143, 16 jan. 2004. Se esses dados se confirmam, eles indicam um custo extremamente baixo de geração de empregos por meio dos créditos do Pronaf.

24 Veja-se a este respeito a entrevista de Ricardo Abramovay no Estado de S. Paulo, 21 dez. 2003.

25 Como observou José Eli da Veiga no artigo já citado (2003), "é da essência microeconômica que a fazenda patronal se desfaça imediatamente de qualquer sobra de braços, enquanto entre agricultores familiares, prevalece a tendência inversa. A propensão do sitiante inovador é evitar a ameaça da redundância, ou retardá-la, graças à diversificação, não apenas de seu sistema produtivo, como também das atividades dos membros da família, antes e depois da porteira". 
26 C arta Capital, 14 jan. 2004 publicou uma surpreendente entrevista de Alain Touraine, intitulada "R eforma urbana já", na qual o sociólogo francês afirma que a reforma urbana é dez vezes mais importante do que a reforma agrária, porque atinge dez vezes mais gente. Touraine considera que não há tempo para esperar que os enormes recursos necessários para a reforma urbana venham do crescimento econômico e propõe, portanto que ela seja financiada pela redistribuição da riqueza às expensas dos 5 ou $10 \%$ mais ricos que notoriamente escapam ao fisco. Concordo com o autor que a reforma urbana é necessária, embora duvide que haja no Brasil condições políticas para seguir a sua proposta. D ivirjo, no entanto, frontalmente da sua subestimação do papel da reforma agrária. Infelizmente, a idéia de que reforma agrária não passa de uma política social é muito difundida nas elites brasileiras. Já ouvi a tese de que seria mais barato oferecer aos sem-terra motocicletas para que virem motoqueiros nas cidades.

27 Por serem não monetários, estes investimentos não estão incluídos no cômputo do PIB. Em certas circunstâncias, o seu volume pode chegar a ser significativo.

$28 \mathrm{~N}$ o mundo atual, vinte milhões de camponeses trabalham com um trator, trezentos milhões usam a tração animal enquanto um bilhão só dispõe de seus braços para trabalhar. Dados da FAO citados por F. De Ravignan. La faim, pourquoi? un défi toujoursd'actualité, Paris, La D écouverte, 2003, p. 79.

29 Françoise Lemoine. L'économi e chi noise, Paris, La D écouverte, 2003, p. 29. D os 168 milhões, $77 \%$ estavam empregados em empresas coletivas e $23 \%$ em empreendi mentos privados e individuais.

30 Trata-se da venda de certificados de carbono previstos pelo Protócolo de Kyoto. Insistimos sobre o fato de que a preferência deve ir a sistemas integrados de produção com fortes impactos so ciais e econômicos e não aos projetos de aflorestamento que constituem a forma mais simples de venda de serviços ambientais.

31 A revolução duplamente verde (evergreen revolution na terminologia do agrônomo indiano M. S. Swaminathan) busca simultaneamente avanços tecnológicos de produtividade e sustentabilidade ambiental. A revolução azul diz respeito à passagem da caça e coleta ao cultivo de espécies que vivem no meio aquático. Ela se encontra ainda numa fase incipiente. As potencial idades do Brasil resultam da combinação de uma extensa faixa litorânea do oceano Atlântico, em parte protegida pelos recifes de coral, com os ecosistemas amazônicos, o Pantanal e, por fim, os numerosos lagos de represa.

32 R umos de set.-out. 2003 publicou uma extensa reportagem sobre esse evento.

33 Essa é também uma área para potencial cooperação entre os pesquisadores brasileiros e indianos. A declaração de Brasília de 6 de junho de 2003, pelos ministros das relações exteriores do Brasil, da África do Sul e da Índia, cita as biotecnologias, as fontes al ternativas de energia e a agricultura, entre os setores científicos e tecnológicos nos quais os três países pretendem ampliar a cooperação.

34 Fonte potencial de cogeração de energia, matéria-prima para produção de papel, de briquetes que substituem o carvão vegetal, de materiais de construção, de fibras para uso industrial e sob forma hidrolizada, ração para gado leiteiro.

350 projeto elaborado pelo Sebrae em colaboração com o M inistério da Reforma 
Agrária contou com a valiosa contribuição dos professores Ademar Ribeiro Romeiro (U nicamp/ IE e Embrapa) Paulo Choji Kitamura (Embrapa/ Cnpma) e Paulo Yoshio Kageyama (U SP/ Esalq, atualmente M M A).

36 Em 2002, a produção mundial de camarão foi de 1,3 milhões de toneladas sobre pouco mais de dois mil hectares e uma produtividade média de apenas $644 \mathrm{Kg} / \mathrm{ha} /$ ano. 0 maior produtor foi a China, com 311 mil toneladas.

37 Ver A. Biondi, "A guerra do camarão - enquanto produtores americanos acusam os brasileiros de dumping, no N ordeste o crustáceo gera fortunas e conflitos" em Carta Capital, 21 jan. 2004, pp. 8-14.

38 D ados citados por Philip C. Scott, em entrevista ao R umos, set.-out. 2003.

39 Segundo certos pesquisadores, faz sentido agregar um módulo de piscicultura nos sistemas integrados de produção de alimentos e energia a partir da cana-de-açúcar, já que o vinhoto pode ser aproveitado como ração para peixes.

40 A presentei este argumento, que figura proeminentemente em vários trabalhos ulteriores de Amartya Sen, no artigo "Welfare State in Poor Countries", em Economic and Political Weekly, Bombay, vol. VI, no 3-4, jan. 1971, pp. 367-370. O sucesso recente da êndia na exportação de software e de serviços baseados nas novas tecnologias de informação e comunicação (NTIC) baseia-se nesta mesma vantagem comparativa.

$41 \mathrm{Em}$ seu primeiro pronunciamento, o novo M inistro do Trabalho Ricardo Berzoini, indicou que pretende dar um grande destaque nas políticas de combate ao desemprego, à cooperação do seu M inistério com os bancos estatais ( 0 Globo, 25 jan. 2004).

420 s industriais chineses do cal çado contrataram numerosos técnicos brasileiros conseguindo uma entrada espetacular no mercado norte-americano, no qual o Brasil encontra dificuldades crescentes em se manter. $N$ umerosas indœstrias maquiladoras no M éxico, local izadas ao longo da fronteira estado-unidense, foram adquiridas por empresários chineses que as fecharam, tranferindo a produção para a China e causando uma grave crise de desemprego no M éxico.

$43 \mathrm{U} \mathrm{m} \mathrm{k}$ alto em atividades de baixa tecnologia é um resultado contra-intuitivo. 0 famoso ambar-charka (roda de fiar) de Gandhi, símbolo da resistência indiana aos britânicos, era muito barato, porém excessivamente pouco produtivo levando o coeficiente capital/ produto $\mathrm{k}$ a um nível bem superior ao prevalecente nas fiações industriais. Já o caso era bem diferente com relação aos teares manuais. Por isso, durante várias décadas, para salvar os empregos artesanais, a êndia aplicou uma política que protegia os tecelões trabalhando em teares manuais com fios de origem industrial.

44 Pensamos que um crédito de imposto associado à geração do primeiro emprego adicional numa microempresa poderia resultar numa expansão significativa de emprego. 0 aprendizado devidamente institucionalizado pode constituir uma forma importante de criação de oportunidades de trabal ho nas microempresas artesanais, como mostra a experiência de vários países industrial izados. Por outro lado, a legislação fiscal atual não é favorável à graduação de M PE s, na medida em que a passagem do Simples para o regime geral implica um grande aumento da carga tributária. 
D ever-se-ia pensar numa maneira de atenuar este choque, prevendo, por exemplo, reduções progressivas da alíquota nos três primeiros anos que seguem à graduação.

45 A legislação atual baseada no princípio de aquisição pelo menor custo não permite incluir outros critérios (sociais e ambientais). N a prática, ela discrimina negativamente os empreendedores de pequeno porte que não têm condições de atender às múltiplas exigências do processo de licitação. Existe também uma discriminação contra as cooperativas de trabalho, como se todas fossem cooperativas de gatos criadas para burlar as leis trabalhistas. As cooperativas de gatos devem ser rigorosamente combatidas. Ao mesmo tempo, deve-se instaurar um regime preferencial para autênticas cooperativas de trabalho.

46 U m importante estudo do Wider (World Institute for Development Economic R esearch) da U niversidade das $\mathrm{N}$ ações U nidas coordenado por Robert $\mathrm{M}$ cl ntyre e Bruno $D$ allago sobre as experiências da transição à economia de mercado dos países do L este europeu mostrou que contrariamente ao que se esperava, o setor de pequenas empresas não é capaz, por si só, de gerar um crescimento econômico bemsucedido. Para que o desenvolvimento aconteça, é preciso criar uma relação sinérgica entre os empreendimentos de pequeno porte e as grandes empresas (U N U / Wider, "Ten Years of Transition: What Success in Building ' $M$ arket E ssence'" , H elsinki, 17 dez. 2003. Por outro lado, o recente escândalo da Parmalat pôs em evidência a existência de um verdadeiro cartel do leite no Brasil, no qual quatro empresas N estlé, Parmalat, Elegê e Paulista - tinham 70\% do mercado, impondo aos pequenos fornecedores de leite preços pouco remuneradores. Atualmente, a N estlé, que antes da crise desencadeada pela concordata da Parmalat pagava $\mathrm{R} \$ 0,52$ por litro, está pagando $\mathrm{R} \$ 0,43$ (“C rise do leite”, 0 Globo, 29 jan. 2004).

47 Veja-se os livros organizados por M árcio Pochmann: D esenvolvimento, trabalho e solidariedade: novos caminhos para a inclusão social, São Paulo, Fundação Perseu Abramo/ Cortez, 2002; A tlas da exclusão social no Brasil, São Paulo, Cortez, 2003 (2 vols.) e Outra cidade éposśv vel - alternativasde inclusão social em São Paulo, São Paulo, Cortez, 2003.

48 U ma maneira de distinguir um produtor protocapitalista de um microempresário capitalista é saber se ele faz a devida distinção entre o bolso da empresa e o bolso familiar.

49 Ver Estudo decar acterização econômi ca do pól o de confecções do A grestePernambucano, relatório final apresentado ao Sebrae-PE em maio de 2003. Esse estudo foi coordenado pelos professores M aria C ristina Raposo e G ustavo M aia Gomes.

I gnacy Sachs é professor honorário na Escola de Altos Estudos em Ciências Sociais (EH ESS) em Paris, e co-diretor do seu Centro de Pesquisas sobre o B rasil Contemporâneo (CRBC).

Texto recebido e aceito para publicação em 12 de maio de 2004. 